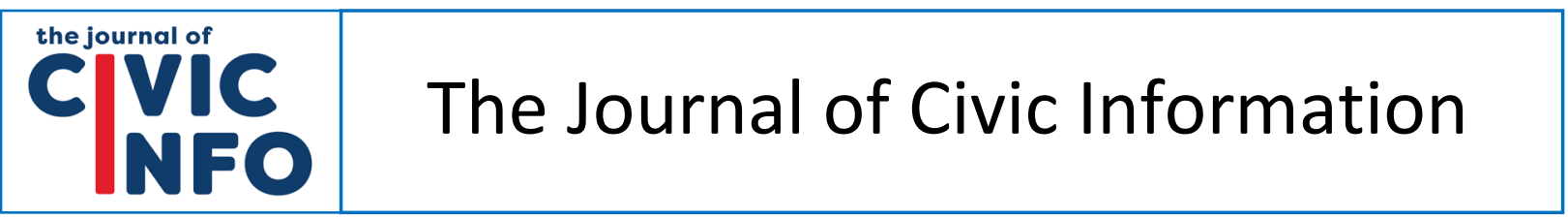

Volume 1 | Number 1

September 2019

Journal homepage: https://journals.flvc.org/civic/

ISSN (online): 2641-970X

\title{
Access to Government Officials in the Age of Social Media
}

\author{
Katie Blevins \& Kearston L. Wesner *
}

Article Information

Received: Jan. 21, 2019

Accepted: Feb. 13, 2019

Published: Sept. 4, 2019

Keywords

Freedom of information

Right to know

Public records

Government transparency

Social media

Public forum

\begin{abstract}
As social media platforms have become more pervasive, there has been a concomitant increase in the number of government officials using their personal social media accounts to perform official government duties. Most notably, President Donald Trump continues to use his personal Twitter account, established in 2009, prior to his presidency, to conduct a variety of official tasks. While the First Amendment's Free Speech Clause traditionally protects an individual's right to engage in self-expression, the Supreme Court has not unequivocally recognized an affirmative right to know as an extension of the First Amendment. Recent court decisions suggest this may change. This study addresses the contours of public access to government officials on social media. Specifically, it considers the circumstances in which government officials are likely to be held to a standard of accountability and the case for treating public officials' social media accounts as public forums, including how factors relating to account ownership and content impact that analysis.
\end{abstract}

* Katie Blevins, University of Idaho; Kearston L. Wesner, Quinnipiac University. Please send correspondence about this article to Katie Blevins at katieblevins@uidaho.edu. An earlier version of this work was presented at the National Freedom of Information Coalition summit FOI Research Competition, April 12, 2019, in Dallas, Texas.

To cite this article in Bluebook: Katie Blevins \& Kearston L. Wesner, Access to Government Officials in the Age of Social Media, 1(1) J. CIVIC INFO 30 (2019).

To cite this article in APA: Blevins, K., \& Wesner, K. L. (2019). Access to government officials in the age of social media. Journal of Civic Information, 1(1), 30-58.

DOI: https://doi.org/10.32473/joci.v1i1.115658

Published under Creative Commons License CC BY-NC, Attribution NonCommercial 4.0 International. 


\section{Introduction}

As social media platforms have become more pervasive, with unprecedented levels of engagement, there has been a concomitant increase in the number of government officials using personal social media accounts to perform official government duties. Most notably, President Donald Trump continues to use his personal Twitter account, which he established in 2009 prior to his presidency, for a variety of official tasks, from making policy announcements to interacting with constituents and world leaders. ${ }^{1}$ Trump's Twitter account has even been characterized as "one of the White House's main vehicles for conducting official business."2 Sean Spicer, then-White House Press Secretary, acknowledged in 2017 that Trump's tweets are "considered official statements by the President of the United States." ${ }^{3}$ This position is consistent with the Presidential Records Act of 1978, which defines "Presidential records" to include materials that the President creates "in the course of conducting activities which relate to or have an effect upon the carrying out of the constitutional, statutory or other official or ceremonial duties of the President."

Social media platforms have become ubiquitous among those with access to the internet. ${ }^{5}$ In 2005, just 5\% of American adults used a social media platform. ${ }^{6}$ As of 2018 , Facebook, the most prominent social media platform, was used by $68 \%$ percent of American adults, $75 \%$ of whom access the platform daily. ${ }^{7}$ In all, in 2018 Facebook had 1.49 billion daily users, and 2.27 billion monthly users. ${ }^{8}$ Twitter is used by nearly one-quarter of all adults; notably, $45 \%$ of the 18 to-24 demographic uses Twitter. Other social media platforms reflect similar staggering growth, especially among that 18 -to- 24 demographic. Snapchat and Instagram are particularly popular; the former is used by $78 \%$ of that population, and the latter is used by $71 \% .{ }^{9}$ Even the non-traditional social media platform YouTube is used by $73 \%$ of adults and $94 \%$ of the 18 -to- 24 population.

Unsurprisingly, political figures have embraced social media to reach their constituents. These officials have also found themselves in a legal quagmire connected to their use of social media to deliver official messages. When these officials block constituents or deny them access to social media posts concerning official duties, what, if any, First Amendment claims are raised? Traditionally the First Amendment's free speech clause protects an individual's right to speak and engage in self-expression. However, the Supreme Court has not unequivocally recognized an affirmative right to know as an extension of the First Amendment. This might be changing.

In May 2018, the United States District Court for the Southern District of New York confronted this question in the context of President Trump's practice of liberally blocking users

\footnotetext{
${ }^{1}$ Donald Trump (@realDonaldTrump),TwITTER,https://twitter.com/realDonaldTrump.

${ }^{2}$ Knight First Amendment Inst. v. Trump, 928 F.3d 226 (2d Cir. 2019).

${ }^{3}$ Aric Jenkins, Sean Spicer Says President Trump Considers His Tweets 'Official' White House Statements, TIME (June 6, 2017), http://time.com/4808270/sean-spicer-donald-trump-twitter-statements/.

${ }^{4} 44$ U.S.C. § 2202. See Knight First Amendment Inst., 928 F.3d at 232 (discussing the application of the Presidential Records Act to President Trump's tweets).

${ }^{5}$ Even in the United States, access to internet is not universal. In 2000, only 50\% of Americans had access to the internet. As of 2018, 89\% of American adults use the internet. Pew Research Center, Internet/Broadband Fact Sheet, 2018, PEW RESEARCH CENTER (Feb. 5, 2018), http://www.pewinternet.org/fact-sheet/internet-broadband/.

${ }^{6}$ Aaron Smith \& Monica Anderson, Social Media Use In 2018, Pew Research Center (Mar. 1, 2018), http://www.pewinternet.org/2018/03/01/social-media-use-in-2018/.

${ }^{7} \mathrm{Id}$. Facebook is also notable for a variety of other reasons: it is the largest global social media platform, and its users reflect a wide variety of demographics.

${ }^{8}$ FACEBOOK NEWSROOM, https://newsroom.fb.com/company-info/.

${ }^{9}$ Smith \& Anderson, supra note 6.
} 
who spoke out or disagreed with him on Twitter. ${ }^{10}$ In holding that this practice violated the First Amendment, the court decried Trump's practice of "viewpoint-based exclusion." "On appeal, the United States Court of Appeals for the Second Circuit agreed that public officials who use social media accounts to conduct official business cannot block people who have expressed disagreement. $^{12}$ That court, however, declined to rule on the more general constitutional question of whether elected officials can exclude individuals from private social media platforms. ${ }^{13}$

Similar issues have arisen elsewhere. For example, in June 2018, a Missouri resident sued a state representative for violating his First Amendment rights by blocking him on Twitter. ${ }^{14}$ And in January 2019, a federal court in Virginia held that an elected official violated the First Amendment by blocking a constituent on Facebook, ${ }^{15}$ and a federal court in Wisconsin granted summary judgment, holding that three Wisconsin state representatives unconstitutionally blocked a liberal advocacy group on Twitter. ${ }^{16}$ These issues will, in all likelihood, continue to spread, given the widespread use of social media by elected officials to reach constituents, as well as a general shift in officials' Twitter "habits" that parallel Trump's approach. ${ }^{17}$

The question this study addresses is this: What are the boundaries of public access to government officials on social media? Traditionally, statutes like FOIA, the Government in the Sunshine Act, and the Presidential Records Act have governed the public's access to official government information. However, the variable of social media use has changed the traditional calculus and raised important questions about the intersection of technology, transparency, and the First Amendment.

This study uses traditional legal research methodology. First, it reviews Supreme Court jurisprudence regarding an affirmative right to know, in order to establish the foundation for the study. Second, it examines the courts' statutory interpretation to clarify the boundaries of public access. And third, it assesses court decisions regarding access to officials' social media accounts as a springboard to explore the relevant legal issues. Throughout the study, the following questions are answered: Under what circumstances are government officials likely to be held to a standard of accountability? What case can be made for a public forum argument? Does this determination depend on whether the social media account is "personal" or "official"? Does the content posted

${ }^{10}$ Memorandum and Order, Knight First Amendment Inst. at Columbia Univ. v. Trump, 1:17-cv-05205-NRB (S.D.N.Y. May 23, 2018),

https://knightcolumbia.org/sites/default/files/content/Cases/Twitter/2018.05.23\%20Order\%20on\%20motions\%20for $\% 20$ summary $\% 20 j u d g m e n t . p d f$.

${ }^{11} I d$.

${ }^{12}$ Knight First Amendment Inst., 928 F.3d at 230. According to the court, "[T]he First Amendment does not permit a public official who utilizes a social media account for all manner of official purposes to exclude persons from an otherwise-open dialogue because they expressed views with which the official disagrees."

${ }^{13} I d$.

${ }^{14}$ Complaint, Campbell v. Reisch, 2:18-CV-04129-BCW (W.D. Mo. June 27, 2018),

https://www.columbiatribune.com/assets/MO30424628.PDF.

${ }^{15}$ Davison v. Randall, 912 F.3d 666 (4th Cir. 2019). See James M. LoPiano, Public Fora Purpose: Analyzing Viewpoint Discrimination on the President's Twitter Account, 28 Fordham InTELL. ProP., MEDIA AND ENT. L.J. 511, 516 n. 23 (2018) (discussing various lawsuits brought by constituents against government officials who had blocked them on Facebook or Twitter).

${ }^{16}$ Opinion and Order, One Wisconsin Now v. Kremer, 3:17-cv-00820-wmc, at*28-29 (W.D. Wis. Jan. 18, 2019), https://drive.google.com/file/d/1OtytYQFFgRZFXqUoVZtfvHnI_lw1SZMn/view.

${ }^{17}$ Ann Marimow, Trump's Twitter Habits Are Affecting How Local Politicians Behave Online, WASHINGTON Post, Mar. 5, 2019, https://www.washingtonpost.com/local/legal-issues/trumps-twitter-habits-are-affecting-how-localpoliticians-behave-online/2019/03/25/bd8bd94c-4be1-11e9-93d0-

64dbcf38ba41_story.html?utm_term=.5a88dabc190a. 
to the account suggest that the account was intended as a public forum? And how does the legal question of access to a public official's social media account fit into our current First Amendment jurisprudence, specifically regarding transparency and a "right to know"?

Clarifying these issues is critical for a variety of audiences: government agencies ensuring that officials' social media use complies with applicable law; FOI advocates fighting for government transparency; and access practitioners seeking to engage with elected officials and exercise their voices. Absent clarification, access to the accounts of public officials is, at best, under threat.

\section{The Supreme Court and the right to know}

The right to know, defined as the public's right to access government-controlled information in the form of records, can be found in common law, statutes, and early administrative law at both the state and federal levels. But this right has a complicated and muddled history.

It was articulated as far back as 1787 , before the U.S. Constitution was ratified, when Constitutional framer James Wilson argued that Congress was obligated to publish its proceedings. He said, "[The] people have a right to know what their Agents are doing or have done, and it should not be in the option of the Legislature to conceal their proceedings." 18 Despite Wilson's passionate defense of the right to know, no clear scholarly consensus suggested that the Founders intended citizens to have access to government information. ${ }^{19}$ Although the Founders may have discussed concepts related to a right to know, these ideas were presented as a political ideal, not a concrete right. ${ }^{20}$ FOI pioneer and advocate Harold L. Cross, who contributed much of the rationale undergirding modern federal freedom of information law, argued, however, that the history of free speech and press "bars any notion that the men of 1791 intended to provide for freedom to disseminate such information but to deny freedom to acquire it." 21

The modern right to know initially appeared in early $20^{\text {th }}$ century Supreme Court opinions. ${ }^{22}$ Beginning in the 1930s, the Supreme Court struggled with whether, and then how, to

18 Journal of the Federal Convention August 11 th 1787, FREEREPUBLIC.COM, http://www.freerepublic.com/focus/fbloggers/2762059/posts. This quote comes directly from the Journal of the Federal Convention from August 11, 1787. This is an historical version of the origination of a right to know that Brian Richardson, respected journalistic ethicist at Washington and Lee University, recognized in one of his publications. Brian Richardson, The Public's Right to Know: A Dangerous Notion, 19(1) J. MASs MEDIA ETHICS 46, 46 (2004). Eventually, the Constitution adopted Wilson's argument, saying, "Each House shall keep a Journal of its Proceedings, and from time to time publish the same, excepting such Parts as may in their Judgment require Secrecy; and the Yeas and Nays of the Members of either House on any question shall, at the Desire of one fifth of those Present, be entered on the Journal." U.S. CONST. art. 1 $\S 5$.

${ }^{19}$ See Martin Halstuk, Policy of Secrecy--Pattern of Deception: What Federalist Leaders Thought About a Public Right to Know, 1794-98, 7 COMM. L. \& POL'Y 51 (2002).

${ }^{20}$ Despite this generally accepted academic view, some instances suggest that the Founders intended to provide for a certain level of governmental transparency. James Wilson's stance that the Legislature should publish their proceedings so that "people have a right to know what their Agents are doing or have done" seems to demonstrate an early preoccupation with a right to know. Journal of the Federal Convention August 11 ${ }^{\text {th }}$ 1787, FREEREPUBLIC.COM, http://www.freerepublic.com/focus/f-bloggers/2762059/posts.

${ }^{21}$ Harold L. Cross, The People's Right to Know: Legal Access to Public Recordings And Proceedings 131-132 (Columbia Univ. Press 1953).

${ }^{22}$ Grosjean v. American Press Co. (1936), the first case to state a First Amendment link to information, invalidated a Louisiana law that taxed newspapers with a circulation of more than 20,000 copies weekly. The newspaper publishers successfully argued that this law violated their First Amendment free speech rights. In a unanimous opinion, Justice Sutherland wrote a compelling history of taxation on the press in pre-colonial England. He explained that these taxes 
recognize a constitutional right to know. Five Supreme Court justices endorsed a limited but constitutionally enforceable right to know during their various tenures. ${ }^{23}$ However, extending any constitutional right is fraught with problems for the judiciary because critics fear that this activity reflects unbridled judicial activism. Yet some constitutional rights exist only because justices elected to extend the shadow of certain constitutional protections. This gray area, or shadow, of the Constitution is known as the penumbra.

Legally, the penumbra comprises the implicit rights granted by a constitution. The concept originated in Justice Stephen J. Field's majority decision in the 1871 case Montgomery v. Bevans. ${ }^{24}$ Penumbral rights have been articulated in different ways. In 1873, Supreme Court Justice Oliver Wendell Holmes disparagingly referred to the penumbra as a "gray area where logic and principles falter." ${ }^{25}$ And in a variety of opinions during his lengthy tenure as a U.S. Court of Appeals judge for the Second Circuit, Judge Learned Hand used the idea of a penumbra when referring to ideas that he deemed poorly defined and/or unclear. ${ }^{26}$

While it is true that penumbral rights have been treated with suspicion and hostility, the fact is that certain deeply valued rights only exist by virtue of the penumbra. In 1965, the Supreme Court created a penumbral right to privacy when it invalidated a Connecticut law that banned contraceptives. ${ }^{27}$ In the majority opinion, Justice Douglas noted that the "First Amendment has a penumbra where privacy is protected from governmental intrusion. In like context, we have protected forms of "association" that are not political in the customary sense, but pertain to the social, legal, and economic benefit of the members." ${ }^{28}$ More than 50 years have passed since that decision, during which the right to privacy has become entrenched in our jurisprudence.

The Supreme Court's First Amendment decisions implicate a constitutionally protected right to know. These cases contain reasoning in majority opinions, dicta, and even dissenting opinions demonstrating that Supreme Court justices have repeatedly considered or assumed that a right to know exists within the penumbra of the First Amendment. This nearly 100-year record clarifies the judiciary's current position regarding government officials' use of social media accounts.

As a threshold matter, relevant Court decisions also speak in terms of a constitutional right to receive information, which was firmly established by the 1960s. For example, in Stanley $v$.

were designed to limit the circulation of ideas contrary to the monarchy. The opinion noted that the Framers rejected these limitations and created the First Amendment. Grosjean v. Am. Press Co., 297 U.S. 233, 250-51 (1936).

${ }^{23}$ Justice Douglas was the most significant advocate for a right to know, though Justices Brennan, Powell, Marshall, and Stevens were equally inclined at times. DAVID O'Brien, The Public's Right to KnOw: The Supreme CourT AND THE FIRST AMENDMENT 60 (Praeger 1981). Justice Brennan, for example, said, "It is a mistake to suppose that the First Amendment protects only self-expression, only the rights to speak out. I believe that the First Amendment in addition fosters the values of democratic self-government." $I d$. at 143. None of these justices currently occupy the bench of the Supreme Court. Concerning this endorsement, the five justices who supported a right-to-know incurred criticism from the majority of their peers. Justice Stewart, for example, argued that extending a right to know to the constitutional penumbra would constitute an unacceptable level of judicial activism. Id. at 62 .

${ }^{24}$ Montgomery v. Bevans, 17 F. Cas. 628 ( $9^{\text {th }}$ C.C.D. Cal.) (1871). This is the case that historically has been referred to as first referencing the idea of a penumbra legally. The case concerned Mexican land grants under the Van Ness ordinance, not a topic that on its surface ties to modern discussions of a penumbra. Id.

${ }^{25}$ Oliver Wendell Holmes, The Theory of Torts, 7 AM. L. REV. 652, 654 (1873). Citing the penumbra is not a common legal idea. Four judges are responsible for the majority of decisions referencing a penumbra: Oliver Wendell Holmes Jr., Learned Hand, Benjamin N. Cardozo, and William O. Douglas. See Burr Henley, 'Penumbra': The Roots of a Legal Metaphor, 15(1) HASTINGS CONST. L.Q. 81 (1987).

${ }^{26}$ Henley, supra, at 87-89.

${ }^{27}$ Griswold v. Connecticut, 381 U.S. 479, 479 (1965).

${ }^{28}$ Id. at 483. 
Georgia, a search of someone's home turned up obscene materials that were illegal under Georgia law. ${ }^{29}$ Even though these materials clearly violated applicable law, the Court refused to criminalize the mere possession of private obscene material. In its holding, the Court protected the individual's First Amendment right to free expression, saying, "[I]t is now well established that the Constitution protects the right to receive information and ideas." 30

The cases analyzed in this section are divided into two areas: access to publicly available information, and access to government information.

\section{Access to publicly available information}

Cases regarding the access to publicly available information help resolve the question of whether the public can successfully assert a right to know and demand access to a government official's social media account. President Trump's Twitter feed, for example, is publicly available. It is only when Trump blocks users that they lose the ability to access his accounts. ${ }^{31}$ When they are blocked, the users lose the ability "to view the President's tweets, to directly reply to those tweets, or to use the @realDonaldTrump webpage to view the comment threads associated with the President's tweets." 32 These cases involve analogous instances in which the public was denied access to information that was otherwise publicly available. The majority of cases fall within this category.

These cases reveal two important points regarding a presumed right to access government officials' social media accounts. First, the Supreme Court has repeatedly held that an individual's right to know is heightened when the desired information is necessary to further the goals of participatory democracy. And second, the government is prohibited from contracting the knowledge available to citizens or creating an undue burden on citizens who seek that information.

\section{The right to know furthers the goals of participatory democracy}

The right to know is perhaps most pronounced when the information at issue involves participation in the political process. Indeed, the Court has explicitly and unequivocally stated the importance of citizens' right to know in a democratically elected state. In Marsh v. State of Alabama, the Court stated that "citizens ... must make decisions which affect the welfare of the community and nation. To act as good citizens, they must be informed. In order to enable them to be properly informed their information must be uncensored." 33

As such, the Court has afforded ample protection for an individual's right to receive information. ${ }^{34}$ Perhaps the clearest and most directly relevant example involved the Supreme Court

\footnotetext{
${ }^{29}$ Stanley v. Georgia, 394 U.S. 557, 557 (1969). Specifically, law enforcement officials entered Stanley’s home with a warrant and searched it in connection with illegal bookmaking activities. In the course of the search, officers found films that they viewed and deemed as obscene, confiscating them and arresting Stanley. Id.

${ }^{30} I d$. at 564 (1969).

${ }^{31}$ In August 2018, President Trump was forced to unblock over forty users who had been blocked from his public Twitter account after a U.S. district judge ruled in May that blocking users violated their First Amendment rights. David Shepardson, Trump Unblocks More Twitter Users After U.S. Court Ruling, REUTERS (Aug. 29, 2018), https:/www.reuters.com/article/us-usa-trump-twitter/trump-unblocks-more-twitter-users-after-u-s-court-rulingidUSKCN1LE08Q.

${ }^{32}$ Knight First Amendment Inst., 928 F.3d at 232.

${ }^{33}$ Marsh v. Alabama, 326 U.S. 501, 508 (1946).

${ }^{34}$ See text accompanying notes 29-30, supra.
} 
upholding the right of individuals to receive political information. In Lamont v. Postmaster General, the Court analyzed a section of the Postal Service and Federal Employees Salary Act of 1962, which required the Postmaster General to deliver communist mailings only upon the recipient's affirmative request. ${ }^{35}$ The Court determined that the postmaster's actions both in withholding information and requiring individuals to request the mailings were unconstitutional. ${ }^{36}$ The Court rationalized that people should be able to receive information in the mail without first having to clear these hurdles.

The Court also considered the right to receive information as a political speech issue in First National Bank of Boston v. Bellotti ${ }^{37}$ In Bellotti, the Court examined the issue of whether corporations had a First Amendment right to make monetary contributions to help influence the political process. ${ }^{38}$ The appellants in this case, a national association of banks and corporations, wanted to spend money to publicize their political view on a referendum to enact a new tax. ${ }^{39}$ They were constrained by an existing Massachusetts statute that made it a crime for organizations to make political contributions or expenditures intended to sway voters. ${ }^{40}$ In a 5-4 ruling, the Court held that corporations have the right to make contributions to the political process. ${ }^{41}$ According to Justice Powell in the majority, this case is less about the rights of the corporation per se than the public's right to the information pertaining to the political contributions. ${ }^{42}$

This basic principle was again articulated in Board of Education v. Pico, a suit brought by schoolchildren who protested the school board's removal of "anti-American, anti-Christian, antiSemitic, and just plain filthy" texts from district's junior high and high school libraries. ${ }^{43}$ In a plurality decision, Justice Brennan wrote that students had a First Amendment right to access available information in the library so they could become more informed citizens. ${ }^{44}$ As the Pico Court explained:

[J]ust as access to ideas makes it possible for citizens generally to exercise their rights of free speech and press in a meaningful manner, such access prepares students for active and effective participation in the pluralistic, often contentious society in which they will soon be members. ${ }^{45}$

While the students obviously could not demand the school board purchase certain books, they had a right to obtain existing information, even in venues, like public schools, that have traditionally limited First Amendment rights.

In a comparatively significant context, two Supreme Court cases involving the distribution of religious information held that the First Amendment protects both the right to distribute and to receive literature. These cases, which involved the prosecution of Jehovah's Witnesses for illegally distributing religious tracts, recognized that the receipt of information is critical to perpetuating

\footnotetext{
${ }^{35}$ Lamont v. Postmaster Gen., 381 U.S. 301, 301 (1965).

${ }^{36} I d$.

${ }^{37}$ First Nat'l Bank of Boston v. Bellotti, 435 U.S. 765 (1978).

${ }^{38} I d$.

${ }^{39} \mathrm{Id}$.

${ }^{40} \mathrm{Id}$.

${ }^{41} I d$.

${ }^{42}$ Id. at $776-77$.

${ }^{43}$ Bd. of Educ. v. Pico, 457 U.S. 853, 853 (1982). This was done contrary to the recommendations made to the school board by a committee of parents and school staff. $I d$.

${ }^{44} I d$. at 854.

${ }^{45} I d$. at 868 .
} 
democratic ideals. In Martin v. City of Struthers, the Court conceded that although distributing literature door-to-door may be "a nuisance," it nevertheless enables "citizens to engage in the dissemination and discussion of ideas, per democratic tenets." 46 According to the Court, "Information enriches public discourse and is a fundamental component of deliberative democracy." ${ }^{47}$ Echoing the Court's rationale in Martin, the Court in Marsh v. Alabama emphasized the privileged role of information in a representative democracy. ${ }^{48}$

The cases thus far involve political information fairly directly, but the Court has read this interest broadly. It has asserted that some information, though not specifically political in nature, can still be vital to participatory democracy. Society as a whole is concerned with preserving democratic principles in ways that fall outside traditional political debate or discourse. ${ }^{49}$ The Supreme Court evaluated these issues in two cases concerning access to reproductive information that is commercial in nature. ${ }^{50}$

First, in Bigelow v. New York, the Court invalidated a Virginia statute that made it a misdemeanor to circulate advocacy that helped individuals procure an abortion. The Court said that citizens were entitled to receive this information - an advertisement that included "information and counseling" for New York abortion services - because it was "factual material of clear 'public interest." 51

And second, in Virginia State Pharmacy Board v. Virginia Citizens Consumer Council, the Court found unconstitutional a statute barring pharmacists from advertising prescription drug prices. ${ }^{52}$ Consumers who challenged the statute argued that it prevented them from comparing prices of prescription medications. ${ }^{53}$ The Court recognized that this impacted consumers, especially "the poor, the sick, and particularly the aged," who had a vested interest in obtaining this life-or-death information. ${ }^{54}$ This interest was of the highest concern: "As to the particular consumer's interest in the free flow of commercial information, that interest may be as keen, if not keener by far, than his interest in the day's most urgent political debate." 55 Therefore, the consumers had a right to know, which stemmed from traditional free speech principles. According to the Court, "Freedom of speech presupposes a willing speaker. But where a speaker exists, as is the case here, the protection afforded is to the communication, to its source and to its recipients

${ }^{46}$ Martin v. City of Struthers, 319 U.S. 141, 143 (1943).

${ }^{47} I d$.

${ }^{48}$ Marsh v. Alabama, 326 U.S. 501, 508 (1946).

${ }^{49}$ Virginia State Pharmacy Bd. v. Virginia Citizens Consumer Council, 425 U.S. 748, 763 (1976).

50 This articulation is particularly interesting because commercial speech traditionally receives reduced First Amendment protection, yet the Court deemed these issues so critical that it was compelled to rule in favor of protection. Originally, commercial speech was not protected under the First Amendment. See Valentine v. Chrestensen, 316 U.S. 52 (1942). The Supreme Court eventually developed a test which provided for limited protection for commercial speech, known as the Central Hudson test. This test asks four questions to determine whether the restriction on speech passes constitutional muster:

1) Is the speech concerning a lawful activity and not misleading?

2) Is the asserted government interest substantial?

3) Does the regulation directly address the government interest?

4) Is the regulation more extensive than necessary to meet that interest?

The government bears the burden of proof in this test. See Central Hudson Gas \& Elec. Corp. v. Public Serv. Comm'n, 447 U.S. 557 (1980).

${ }^{51}$ Bigelow v. Commonwealth of Virginia, 421 U.S. 809, 812 \& 822 (1975).

52 Virginia State Pharmacy Bd., 425 U.S. at 748 (1976).

${ }^{53} \mathrm{Id}$.

${ }^{54} \mathrm{Id}$.

${ }^{55} I d$. at 763 . 
both. ${ }^{56}$ Access here functioned as a mechanism to thwart paternalism and ignorance. ${ }^{57}$ This decision was driven by an analysis of democratic principles and societal interests. ${ }^{58}$

The Bigelow and Virginia State Pharmacy Board cases may appear to be outliers because they involve sensitive medical information. However, the Court has decided other pure commercial speech cases similarly. The Court protected commercial speech interests in real estate "For Sale" and "Sold" signs, asserting that the "societal interest in "the free flow of commercial information' [...] is in no way lessened by the fact that the subject of the commercial information here is realty rather than abortions or drugs." ${ }^{59}$ It also prioritized the public's interest in receiving advertisements from attorneys over the State Bar of Arizona's interest in propounding professional values by restricting those same commercial advertisements. ${ }^{60}$

The principles intrinsic to these cases would support protecting an individual's access to public officials' social media posts. Being able to view and respond to policy announcements and statements associated with the officials' duties is critical to participatory government. Without access, fruitful dialogue is stymied.

The government cannot contract available knowledge or impose an undue burden on obtaining information

The government cannot act capriciously by curbing knowledge to which the public already has access.

This issue has arisen with some frequency in cases involving access to reproductive health information, from sex education to contraceptive counseling for couples and information for sexual assault victims. The cases have uniformly upheld the individual's right to obtain critical health information. In Griswold v. Connecticut, for example, the Court invalidated a statute that criminalized dispensing contraceptives or information about contraception. ${ }^{61}$ The executive director of the Planned Parenthood League of Connecticut and its medical director, a licensed physician, were convicted as accessories under this statute, partly for providing contraceptive devices to couples, and partly for giving "information, instruction, and medical advice" to stop conception. ${ }^{62}$ The Court specifically articulated the individuals' right to know, saying that the "right of freedom of speech and press includes not only the right to utter or to print, but the right

\footnotetext{
${ }^{56} I d$. at 756.

${ }^{57}$ Id. at 770 (decrying the board's "highly paternalistic approach" that functions to "keep[ ] the public in ignorance."

${ }^{58}$ Extending Justice Blackmun's argument, society may also benefit from protecting consumer information. Using the informed democracy approach, Blackmun noted that "[a]dvertising, however tasteless and excessive it sometimes may seem, is nonetheless dissemination of information as to who is producing and selling what product, for what reason, and at what price. So long as we preserve a predominantly free enterprise economy, the allocation of our resources in large measure will be made through numerous private economic decisions. It is a matter of public interest that those decisions, in the aggregate, be intelligent and well informed. To this end, the free flow of commercial information is indispensable." Id. at 765.

${ }^{59}$ Linmark Assocs., Inc. v. Township of Willingboro, 431 U.S. 85, 92 (1977)

${ }^{60}$ Bates v. State Bar of Ariz., 433 U.S. 350, 364-65 (1977). Justice Blackmun quoted from Arizona Justice Holohan's dissenting opinion in the lower court, which said, "Obviously the information of what lawyers charge is important for private economic decisions by those in need of legal services. Such information is also helpful, perhaps indispensable, to the formation of an intelligent opinion by the public on how well the legal system is working and whether it should be regulated or even altered. . The rule at issue prevents access to such information by the public." Id. at 358 .

${ }^{61}$ Griswold v. Connecticut, 381 U.S. 479, 479 (1965) (emphasis added).

${ }^{62} I d$. at 480 .
} 
to distribute, the right to receive, the right to read." 63 As a result, "[T] $]$ he State may not, consistent with the spirit of the First Amendment, contract the spectrum of available knowledge." 64 Even Justice Stewart acknowledged in his dissent that had the directors of Planned Parenthood merely advised people on the use of contraceptives, they would have had a strong First Amendment freespeech claim. ${ }^{65}$

This same rationale guided the Court in Pico. ${ }^{66}$ The students in Pico protested the widespread censorship of materials in the library, but access to those materials was critical. Once the information was generally made available to the students, the school board could not limit that information without substantial justification, and certainly not with an eye to "prescribe what shall be orthodox in politics, nationalism, religion, or other matters of opinion." ${ }^{67}$ While the students obviously could not demand that the school board purchase certain books, they had a right to obtain existing information, even in venues like public schools, which traditionally have limited First Amendment rights.

Similarly, the government cannot impose an undue burden on citizens exercising their right to know certain information. This is why the Court rejected the postmaster's claims in Lamont. It declined to allow the postmaster to impose any type of duty on recipients to affirmatively request communist literature. ${ }^{68}$

In the context of social media accounts, otherwise public accounts that contain political content, such as President Trump's account, should be made available for users to access. These accountholders should be prohibited from engaging in viewpoint discrimination to block users. Purported "solutions" that impose barriers on blocked individuals to regain access are insufficient. Demanding that blocked individuals engage in additional actions to access content would contravene existing right-to-know and undue-burden cases. The only effective solution is to provide legally robust protections that protect users from being blocked to begin with.

\section{Access to compelled government information}

This study has thus far focused on accessing information that was or could be publicly available, such as political and religious information, reproductive health information, and commercial information. The issues presented are far different when that information is not generally available to the public. A narrower and more contentious line of cases purport to establish what rights, if any, individuals have to compel the release of government information. If a public official has a private social media account, is there a First Amendment justification for making that account public?

\footnotetext{
${ }^{63} \mathrm{Id}$. at 482.

${ }^{64} \mathrm{Id}$.

${ }^{65} I d$.

${ }^{66}$ See Bd. of Educ. v. Pico, 457 U.S. 853 (1982), discussed supra in text accompanying notes 43-45.

${ }^{67} \mathrm{Id}$. at 871-872.

${ }^{68}$ Lamont v. Postmaster Gen., 381 U.S. 301, 301 (1965). Historically, the Courts are hesitant to impose any barriers to gathering information. Although the context was wildly different, the Court demonstrated the same commitment to the free flow of information when it invalidated the "segregate and block" portions of the Cable Television Consumer Protection and Competition Act of 1992. Denver Area Educ. Telecomms. Consortium, Inc. v. FCC, 518 U.S. 727 (1996). These provisions required cable providers to block "patently offensive" programming, which could be restored only after the consumer sent in a written request. $I d$. at 754. The Court said these provisions were "overly restrictive, sacrificing important First Amendment interests for too speculative a gain." Id. (internal citations and quotations omitted).
} 
Typically, the Court has declined to force the government to reveal information. Because the Constitution lacks an explicit right to know information, individuals lack a mirror right to compel that information.

This rationale has been used in several cases, all involving access to jails or prisons, to deny journalists access to information. In Pell v. Procunier, the Supreme Court held that the media has "no constitutional right of access to prisoners or their inmates beyond that afforded the general public." 69 Similarly, in Saxbe v. Washington, the majority held that prohibiting interviews between the press and federal inmates was constitutional because it "does not deny the press access to sources of information available to members of the general public." 70 Finally, the Court, in Houchins v. KQED, rejected a radio and television broadcaster's request to enter the county jail. ${ }^{71}$ Like the Saxbe Court, it noted that the press had alternative avenues, such as federal access statutes, to obtain pertinent information. ${ }^{72}$ In the plurality opinion, Justice Warren Burger said, "This Court has never intimated a First Amendment guarantee of a right of access to all sources of information within government control." 73 In terms of a right to know, the public and press only have a freedom to "communicate information once it is obtained," not to force information to be revealed. ${ }^{74}$

This rationale has also been used to exclude the press and public from criminal trials. In Richmond Newspapers $v$. Virginia, the Supreme Court evaluated the constitutionality of closed criminal trials and closed records concerning these trials. ${ }^{75}$ The Court considered the First Amendment implications of excluding the public and press. ${ }^{76}$ The various opinions in this case articulated that the right to attend criminal trials is covered within an existing and protected First Amendment right to know. ${ }^{77}$ Criminal trials had historically been open, ${ }^{78}$ which helped ensure the veneer of justice because attendees could confirm the fair treatment of accused criminals. ${ }^{79}$ Justice Burger also stated that the freedoms of speech and the press entail a right to gather information by attending trials. ${ }^{80}$ Under the First Amendment's right to receive information and ideas, the free

\footnotetext{
${ }^{69}$ Pell v. Procunier, 417 U.S. 817, 834 (1974).

${ }^{70}$ Saxbe v. Washington, 417 U.S. 843, 843 (1974).

${ }^{71}$ Houchins v. KQED, Inc., 438 U.S. 1, 1 (1978).

${ }^{72} I d$. at 14 . Additionally, although the conditions in the jail are of great public importance, the media are "ill-equipped" to deal with prison administration. $I d$. at 8 .

${ }^{73} I d$. at 9 . This quote from the Court implies that there are definitely circumstances where the First Amendment does protect a limited right to know, much like the federal access statutes. This case is just an instance where that right to know does not extend.

${ }^{74} I d$. at 2. Justice Stevens, in a dissent with Justices Brennan and Powell, protested on the grounds that excluding the press and public could raise intermediate scrutiny issues. He acknowledged that the "Court has never intimated that a nondiscriminatory policy of excluding entirely both the public and the press from access to information about prison conditions would avoid constitutional scrutiny." Id. 19-27 (Stevens, J., dissenting).

${ }^{75}$ This was the first time that access to trials was specifically examined. The Richmond Court discussed Gannett Co. v. DePasquale, 443 U.S. 368 (1979), a similar decision, in which the Supreme Court examined the right of access to hearings and pretrial motions. In DePasquale, the trial judge closed the defendant's fourth murder trial at the behest of his defense counsel, who sought to reduce prejudicial publicity. Although the appellant's counsel cautioned that constitutional rights could be implicated in the closure, the trial judge ordered the trial closed and excluded both the press and public. Richmond Newspapers v. Virginia, 488 U.S. 555, 564 (1980).

${ }^{76}$ Richmond Newspapers 488 U.S. at 558.

${ }^{77} I d$. at 556.

${ }^{78} \mathrm{Id}$. at 569 (stating that "criminal trials both here and in England had long been presumptively open"). For a more detailed history of openness of trials in England and the U.S., see id. at 564-69.

${ }^{79} \mathrm{Id}$. at 572. Justice Brennan and Justice Marshall also pointed out the need for ensuring a fair trial in their special concurrence. Id. at 557.

${ }^{80} I d$. at 576. Justice Burger also drew upon the right to assemble in conjunction with the free speech and press clauses. Id. at $577-78$.
} 
speech and press clauses "prohibit [the] government from summarily closing courtroom doors that had long been open to the public at the time the First Amendment was adopted." 81

In a special concurrence, ${ }^{82}$ Justice Stewart wrote that while the First and Fourteenth Amendments gave the public and press the right to attend all trials, both criminal and civil, this right was limited. ${ }^{83}$ Some circumstances, including space limitations, safety concerns, and privacy of minors, could warrant limiting the attendance of the press and/or the public at trial. ${ }^{84}$

Justice Stevens, in a regular concurrence, noted the precedential importance of this case: "[F]or the first time, the Court unequivocally holds that an arbitrary interference with access to important information is an abridgement of the freedoms of speech and of the press protected by the First Amendment." 85 This case demonstrates that press members, as representatives of the public, realize rights equal to the public's. Richmond does not just grant a First Amendment right to attend criminal trials; it also creates a limited First Amendment right to know because it includes access to records related to those trials. Although this First Amendment right to know is limited, previous cases clarify that the Supreme Court intends a reciprocal constitutional protection for access to some categories of government information as well as freedom of expression.

This guarantee of openness also extends to the voir dire examination of jurors. ${ }^{86}$ In PressEnterprise Co. v. Superior Ct. (Press-Enterprise I), the Court clarified that the principle of openness also covered the records generated during voir dire. ${ }^{87}$ In this instance, records functionally replace attendance at voir dire proceedings, indicating that there should be equal weight given to attendance at meetings and trial proceedings and records from those meetings and proceedings.

Similarly, in Press-Enterprise Co. v. Superior Ct. (Press-Enterprise II), the Supreme Court held that preliminary hearings are "sufficiently like a trial" to justify comparable openness. ${ }^{88}$ Although the defendant's right to a fair and impartial trial must be balanced against the public's right of access, the "explicit Sixth Amendment right of the accused is no less protective of a public trial than the implicit First Amendment right of the press and public." 89 This includes access to preliminary hearings in person, and, when these hearings are closed for specific reasons, eventual access to transcripts of these hearings. To withhold even a transcript would "frustrate what [the Court has] characterized as the "community therapeutic value" of openness." 90

The Supreme Court offers significantly less guidance in determining whether a public official can keep private an otherwise public social media account. There are some limited

\footnotetext{
${ }^{81} I d$. at 576 . This extension of the First Amendment to protection of criminal trials was argued as natural by Justice Burger. Access to trials is an implicit part of the penumbra of the First Amendment. Id.

${ }^{82}$ A special concurrence is one where the justice agrees with the Court's disposition but not its opinion. This is in contrast to a regular concurrence, where the justice agrees with the Court's disposition and opinion.

${ }^{83}$ Richmond Newspapers, 488 U.S. at 598-601. In Justice Burger's opinion, the issue of attendance at civil cases was not addressed, but Burger acknowledged that "historically both civil and criminal trials have been presumptively open." Id. at 569.

${ }^{84} I d$. at $598-601$.

${ }^{85} \mathrm{Id}$. at 583.

${ }^{86}$ Press-Enterprise Co. v. Superior Ct., 464 U.S. 501, 501-505 (1984). The process of jury selection is "itself a matter of importance, not simply to the adversaries but to the criminal justice system." In this ruling, Justice Burger echoed the reasoning from Richmond, citing the history of openness of trial proceedings as well as the use of openness to enhance the actual and perceived fairness of criminal trials. $I d$. at 501-505

${ }^{87} I d$. at 512 (stating that " $[\mathrm{w}]$ hen limited closure is ordered, the constitutional values sought to be protected by holding open proceedings mat be satisfied later by making a transcript of the closed proceedings available").

${ }^{88}$ Press-Enterprise Co. v. Superior Ct., 478 U.S. 1, 12 (1986).

${ }^{89} \mathrm{Id}$. at 7.

${ }^{90} I d$. at 13 .
} 
circumstances where the Supreme Court has compelled the government to provide information to the public under an extension of the First Amendment, although this extension has been limited to checks on the judicial and criminal process. It is likely that private social media accounts of public officials would not rise to this narrow standard and the expectation is that they could remain semiprivate. $^{91}$

\section{Statutory access to government information}

Although the overview of relevant Supreme Court cases ${ }^{92}$ clarified that the Court recognizes a substantive right to know, there are inadequate discrete mechanisms in place to safeguard that constitutional right. ${ }^{93}$ The right to know may be a presumed penumbral right, but it is not explicitly articulated in the First Amendment. ${ }^{94}$ To tackle this problem, the federal government has instead relied on statutes to delineate the boundaries of government transparency and outline the precise contours of the public's legal right to know about government affairs. ${ }^{95}$

Reliance on statutes to safeguard these vital rights, however, presents two serious issues. First, statutes are ill-equipped to combat the inertia of long-standing government opacity. Statutory relief can be painfully slow and yield, at best, inconsistent results. Furthermore, statutes are inherently less stable than fundamental constitutional protections. They are more easily altered and subject to political whims. And second, transparency statutes apply only to records under government control. While these statutes may cover many records desired by individuals seeking access, certain critical documents are outside the statute's ambit. This section of the study addresses both issues and ultimately suggests that mutable statutory solutions should be eschewed in favor of strengthened constitutional protections.

\footnotetext{
${ }^{91}$ These accounts could remain only semi-private because the courts have consistently ruled that we do not have an expectation of privacy in a legal sense to most electronic communications, especially on semi-public forums like social networking sites. It is unlikely that a right to know would extend a requirement that public officials automatically make public an otherwise private account, or mandate that all constituents be "friended" to access an otherwise private account.

${ }^{92}$ See discussion supra section "The Supreme Court and the right to know," p. 33.

${ }^{93}$ Kent Cooper, then Director of the Associated Press, stated that the right to know is not explicitly mentioned by the Constitution but that there should be a constitutional right to know. KENT COOPER, THE RIGHT TO KNOW: AN EXPOSITION OF the EVILS OF NEWS SUPPRESSION AND PROPAGANDA 17 (1956). See, e.g., Houchins v. KQED, 438 U.S. 1 (1978); Pell v. Procunier 417 U.S. 817 (1974); Saxbe v. Washington Post Co., 417 U.S. 843 (1974).

${ }^{94}$ These "unenumerated" nature of these rights leave them particularly vulnerable to challenge. For example, the Supreme Court's decision in Roe v. Wade has protects a penumbral right of privacy. The resulting opinion rests on a "shaky foundation," which many scholars anticipate will be challenged. See Harold R. Demoss, Jr. \& Michael Coblenz, An Unenumerated Right: Two Views on the Right of Privacy. 40 TEX. TECH L. REV. 249, 258 (2008).

${ }^{95}$ See, e.g., Freedom of Information Act, 5 U.S.C. § 552 (1991 \& Supp. 2003); Government in the Sunshine Act, 5 U.S.C. $\S 552 b$ (2011); Federal Advisory Committee Act, 5 U.S.C. App (1972). State access laws originated much earlier than similar federal laws. Alabama passed the first comprehensive open meetings law in 1915 and was still the only state in 1950 to have one. ANN TAYLOR SCHWING \& CONSTANCE TAYLOR, OPEN MEETING LAWS 6-7 (Fathom 1994). Many states that had not yet passed open records laws did so in the wake of the Watergate scandal, as concerns about government transparency grew considerably during this time. State open meetings laws were generally passed later. Florida passed the first state open meeting law in 1967. All fifty states now have some form of open record and meetings laws. $I d$. at 3 .
} 
Statutory protection yields inconsistent results

Relying on statutes to protect the right of access has yielded, at best, inconsistent results. These statutes are ill-equipped to tackle the unique challenges presented by entrenched government opacity. This study will use the most prominent federal statute, the Freedom of Information Act (1966) (FOIA), to illustrate the dangers presented by this inconsistency.

In 1955, U.S. Rep. John E. Moss (D-Calif.), the reform-minded chair for the Special Government Information Subcommittee, sought to assess issues regarding government transparency. He launched congressional hearings regarding the Administrative Procedures Act, a predecessor to FOIA. ${ }^{96}$ The hearings, which occurred before the eventual enactment of FOIA, lasted for ten years and involved hundreds of witnesses. ${ }^{97}$ Not a single agency supported the proposed law. ${ }^{98}$ The bill that would eventually become FOIA, S. 1160, painstakingly proceeded through several iterations before its passage by the Senate in 1965 and House in $1966 .{ }^{99}$ President Lyndon B. Johnson eventually signed the bill into law - reluctantly. ${ }^{100}$ The law's enactment rendered nearly 100 governmental agencies accountable to public demands for information. ${ }^{101}$ Still, numerous entrenched institutional barriers perpetuated an atmosphere of secrecy. Many agencies, accustomed to long-standing opacity, were disinclined to produce records that satisfied citizens' requests. And, worse, most agencies assumed that executive privilege would supersede FOIA, an attitude that sustained the government's preferred policy of secrecy. ${ }^{102}$

The dangers of inertia revealed themselves again in 1996 when FOIA was updated and amended by the Electronic Freedom of Information Act (E-FOIA). ${ }^{103}$ One significant provision of E-FOIA was that it redefined agency records to include information archived in any format, including electronic documents. ${ }^{104}$ Prior to E-FOIA, the guaranteed right of access did not include electronic records. ${ }^{105}$

More clearly than any other amendment, E-FOIA revealed a chasm between innovation specifically technical innovation - and legislative action. The existence of this gap threatens the

\footnotetext{
96 JAMES T. O’REILly, FEDERAL InFORMATION Disclosure 2:02, 2-5 (1994). Congressman Moss was instrumental in establishing the groundwork necessary to document systematic manipulation of governmental transparency by the executive branch. $I d$. at 11 .

${ }^{97} I d$. at 2-5. Of all the witnesses representing agencies, none supported the FOIA. Id. at 3-8, 3-9.

${ }^{98} I d$. at 3-8-9 (1994).

99 JAMES T. O’REILLY, FEDERAL INFORMATION DiSCLOSURE 2:4 (1990).

100 President Johnson's signed the bill believing, “[t]his bill in no way impairs the President's power under our Constitution to provide for confidentiality when the national interest so requires. There are some who have expressed concern that the language of this bill will be construed in such a sway as to impair Government operations. I do not share this concern.” JAMES T. O’REILly, FEDERAL INFORMATION DisClosure 2:5 (1990). President Johnson obviously believed that the FOIA would have no real impact on the state of government transparency.

${ }^{101}$ Freedom of Information Act, 5 U.S.C. $§ 552$ (1991 \& Supp. 2003). Notably, the FOIA does not apply to records held by Congress, state and local governments, the courts, private individuals and entities, the President and the President's personal staff or advisors. Nine exemptions address certain categories of information that agencies may withhold from public disclosure: (1) classified and national security information; (2) internal agency personnel information; (3) information exempted by statutes; (4) trade secrets and confidential business information; (5) agency memoranda; (6) disclosures of personal privacy; (7) records of law enforcement and investigations; (8) some reports of financial institutions; (9) geological and geophysical information. Id.

102 JAMES T. O'REILLY, FEDERAL INFORMATION DiSCLOSURE 15 (1990).

103 See Pub. L. 104-231, 110 Stat. 3048, §§ 1-2 (1996) (amending sections of 5 U.S.C. $§ 552)$.

104 Pub. L. 104-231, 110 Stat. 3048, $\S \S 1-2$ (1996) (amending sections of 5 U.S.C. $\S ~ 552)$.

${ }^{105}$ Martin Halstuk \& Bill Chamberlin, Open Government in the Digital Age, 78(1) JOUR. AND MASS COMM. 45, 45 (2001). Prior to 1996, judges determined appropriateness of access to electronic information, case-by-case. Id. at 48.
} 
public's right to access crucial information. ${ }^{106}$ Even after E-FOIA's passage, its actual implementation was sluggish. To illustrate, a public interest group examining 57 agencies two full years after passage of E-FOIA showed that not a single agency had fully complied with E-FOIA's provision requiring agencies to publish on the internet. ${ }^{107}$ Even in the face of a clear directive, agencies still embraced outmoded mechanisms to support access.

Another issue is that statutes are inherently more susceptible to amendment and political whim than fundamental constitutional protections. ${ }^{108}$ For example, the Department of Justice, which is often subject to political pressure from the executive branch, has the statutory responsibility for overseeing FOIA compliance. ${ }^{109}$ In reality, federal regulatory and administrative agencies self-regulate. The Supreme Court has been complicit in these agency tactics since the 1970s. In fact, many Supreme Court decisions have clearly contravened FOIA's purpose reducing the categories of information available, and preferentially balancing competing interests, such as confidentiality and privacy.

\section{Transparency statutes are limited to records under government control}

Transparency statutes have always been limited to records under government control. FOIA applies to records held by federal agencies and departments, including the Executive Office of the President, ${ }^{110}$ but it does not apply to records held by Congress, the judiciary, private corporations, or private citizens. ${ }^{111}$

During the 1970s and '80s, several Supreme Court decisions limited FOIA to a reactive statute. According to the Court, FOIA could not compel government agencies to create documents; it could only require those agencies to release documents already in existence. ${ }^{112}$ Even if lawfully created agency records did exist, but were misplaced outside of agency jurisdiction, those records could not be compelled. ${ }^{113}$ Furthermore, records generated by private companies that contracted with the government could not be considered agency records unless they were held by federal executive agencies. ${ }^{114}$

\footnotetext{
106 Id. at 57.

107 Jennifer Henderson \& Patrick McDermott, Arming the People “...With The Power Knowledge Gives”: An OMB Watch Report on the Implementation of the 1996 "EFOIA" Amendments to the Freedom of Information Act, OMB Watch (1998), cited in Martin E. Halstuk, Speed Bumps on the Information Superhighway: A Study of Federal Agency Compliance with the Electronic Freedom of Information Act of 1996, 5 COMM. L. \& POL'Y 423, 424 (2000).

${ }^{108}$ In other words, FOIA is not subject to "strict scrutiny" - the highest level of scrutiny required to settle constitutional questions pertaining to free speech, free assembly, and freedom of the press rights. Legal Information Institute, Strict Scrutiny (2010), http://www.law.cornell.edu/wex/strict_scrutiny.

${ }^{109}$ Freedom of Information Act, 5 U.S.C. $§ 552$ (1991 \& Supp. 2003); Government in the Sunshine Act, 5 U.S.C. $\S 552$ b (2011).

${ }^{110}$ Freedom of Information Act, 5 U.S.C. $§ 552$ (1991 \& Supp. 2003). FOIA also covers records of independent regulatory agencies, such as the Federal Communications Commission, the Securities and Exchange Commission, and so on.

${ }^{111} I d$. FOIA also does not apply to state or local governments.

112 N.L.R.B. v. Sears, Roebuck \& Co., 421 U.S. 132, 162 (1975) (holding that an agency cannot be compelled to "produce or create explanatory material" pursuant to a document request).

${ }^{113}$ Kissinger v. Reporters Committee for Freedom of the Press, 445 U.S. 136, 139 (1980) (holding that federal courts have no authority to compel requested documents in the possession of a party that is not an agency).

${ }^{114}$ Forsham v. Harris, 445 U.S. 169, 171-172, 184 (1980) (holding that "written data generated, owned and possessed by a privately controlled organization receiving federal study grants are not "agency records" "under FOIA, and that the agency must actually obtain the record for it to be deemed a record).
} 
Federal employees have taken advantage of this loophole, either inadvertently or intentionally. A 2015 Government Business Council survey of 412 federal employees found that $33 \%$ of surveyed employees use personal email at least sometimes. ${ }^{115}$ Unless agencies establish specific protocols, email sent using a personal device means that the agency does not have a copy of that record, putting it outside of agency control. Thirty-one percent of respondents indicated that their agency did not archive personal email involving government business; another 47\% stated that they did not know their agency policy. ${ }^{116}$ Twenty-seven percent of respondents cited "potential FOIA requests" as a reason that inhibits candid internal email communication within their department/agency. ${ }^{117}$

It seems insufficient to use mutable statutory protections to guarantee access to even a retroactive record of public officials' social media accounts. Not only are existing transparency statutes inconsistently used, leading to uneven distribution of public records, the majority of the social media accounts at issue would not even constitute a public record under existing definitions. Social media accounts are owned by private corporations, and the government does not have the power to compel those records to be made publicly available.

\section{Access to public officials' social media accounts}

The "right to know" cases addressed thus far in this study ${ }^{118}$ analyzed the individual's general right to access information, whether that information is already publicly available or the individual is seeking to compel its release. None of these cases, however, have addressed the specific issue of accessing public officials' speech on social media. And the statutory protections safeguarding access to information are inconsistently applied, inapplicable, or ineffective.

This section analyzes the question of when a public official's social media account should be deemed a public forum. It first discusses the parameters of forum analysis, considering the various guidelines used to ascertain whether a space, whether physical or virtual, qualifies as a public forum. Next, this section briefly addresses, and rejects, the application of the "government speech" doctrine to the issues presented here. Then, it conducts an in-depth analysis of the most salient Supreme Court case, Packingham v. North Carolina, ${ }^{119}$ in which the Court discussed the status of social media as a public forum. It finally turns to an analysis of the two main factors that courts should consider when assessing the public forum status of a social media account:

(1) Is the account "personal" or "official"?

(2) Does the content posted to the account suggest that it is intended to function as a public forum?

Although these issues are not in and of themselves determinative, they provide guidance to courts considering whether to preserve the right of the public to access the account.

\footnotetext{
115 Daniel Pitcairn \& Zoe Grotophorst, The State of Internal Workplace Communication, GOVERNMENT EXECUTIVE (Mar. 5, 2015), https:/www.govexec.com/insights/state-internal-workplace-communication/106737/.

${ }^{116} \mathrm{Id}$.

${ }^{117} \mathrm{Id}$.

${ }^{118}$ See discussion supra section "Supreme Court and the right to know," p. 33.

${ }^{119}$ Packingham v. North Carolina, 137 S. Ct. 1730 (2017).
} 


\section{Forum analysis}

The question of whether, and to what extent, government officials can block constituents or limit their access to official social media posts depends on how these social media accounts are characterized. The government's authority to restrict or limit speech is defined by the forum in which that speech occurs. There are four types of fora, each of which entails varying levels of First Amendment Protection: nonpublic fora, traditional public fora, designated public fora, and limited public fora. ${ }^{120}$ When speech occurs in a public forum, the government's ability to regulate discourse is severely constrained.

Some spaces are nonpublic fora. In these spaces, the government can impose various speech restrictions as long as they are reasonable. ${ }^{121}$

On the opposite end of the spectrum are traditional public fora, which receive the highest level of First Amendment protection. These fora include physical spaces, like streets and parks, that are traditionally used by the public to assemble and discuss public questions. ${ }^{122}$ To curb speech in these spaces, the government must demonstrate that the regulation survives strict scrutiny; thus, it must show it has a compelling state interest, and its restriction(s) must be narrowly tailored. ${ }^{123}$ The government can also impose content-neutral time, place or manner restrictions. ${ }^{124}$

In the middle are designated public fora and limited public fora. Designated public fora include spaces specifically set aside by the government for public speech and expression. These designated public fora are entitled to the same heightened First Amendment protection as traditional public fora. However, they lack the same robustness of traditional public fora because the government is still entitled to reclassify a designated public forum as a private space. ${ }^{125}$ Thus, protecting free speech in these spaces is, to some extent, subject to government whim. ${ }^{126}$ Limited public fora are different because they allow enhanced speech restrictions according to "the limited and legitimate purposes for which [the space] was created." 127 The government opens the space for public discourse, but it can limit the content of conversation within that space. In these spaces, the government is only prohibited from engaging in viewpoint discrimination. ${ }^{128}$

Public forum analysis cases often speak in terms of physical space, but the concept of a "public forum" is far broader. In Rosenberger $v$. Rector and Visitors of University of Virginia, the Supreme Court held that the University of Virginia engaged in unconstitutional viewpoint discrimination when it denied a Christian student organization's reimbursement request to the Student Activities Fund ("SAF"). ${ }^{129}$ Even though the SAF was a forum "more in a metaphysical than in a spatial or geographic sense," the same analysis applies. ${ }^{130}$ By opening up SAF funds to

\footnotetext{
${ }^{120}$ See Lyrissa Lidsky, Public Forum 2.0, 91 B.U. L. REV. 1975 (2011), http://scholarship.law.ufl.edu/facultypub/155. Lidsky's article addresses the "maze of categories" involved in determining what level of scrutiny to apply to government speech restrictions.

${ }^{121}$ Perry Educ. Ass'n v. Perry Local Educators' Ass'n, 460 U.S. 37, 46 (1983).

${ }^{122} I d$. at 45 .

${ }^{123} \mathrm{Id}$.

${ }^{124} \mathrm{Id}$

${ }^{125} \mathrm{Id}$.

${ }^{126}$ Lyrissa Lidsky refers to designated public fora as "a vexed First Amendment category thanks to an ambiguous footnote in the ... Perry decision." Lidsky, supra note 120, at 1983.

${ }^{127}$ Rosenberger v. Rector \& Visitors of Univ. of Virginia, 515 U.S. 819, 829 (1995).

${ }^{128} \mathrm{Id}$.

${ }^{129} \mathrm{Id}$.

${ }^{130} \mathrm{Id}$.
} 
student organizations, UVA created a "limited public forum" and was limited by the attendant boundaries, among which is a restriction on viewpoint discrimination.

Lyrissa Lidsky's article, Public Forum 2.0, notes that "[b]etween the extremes of no interactivity and full interactivity, it is difficult to predict whether courts will label a governmentsponsored social media presence a public forum or not." ${ }^{131}$ Certainly, a social media account may qualify as a public forum. As Lidsky noted, "[I]nteractive social media can foster citizens' First Amendment rights to speak, receive information, associate with fellow citizens, and petition government for redress of grievances." ${ }^{132}$ However, absent a clear indication from the government official that the account is intended to serve as a public forum, the court will be required to analyze the account's characteristics and use to make this determination. The official's intent can be inferred from " "policy and practice' and whether the property is of a type compatible with expressive activity." "133 If the government official has created a limited public forum, then speakers can be excluded for "reasonable and viewpoint neutral" reasons. ${ }^{134}$ This would not protect officials targeting users who express contrary views.

The U.S. Court of Appeals for the Second Circuit, considering the characteristics of Trump's account, determined that it functioned as a public forum:

The Account was intentionally opened for public discussion when the President, upon assuming office, repeatedly used the Account as an official vehicle for governance and made its interactive features accessible to the public without limitation. We hold that this conduct created a public forum. ${ }^{135}$

It also noted that "[i]f the Account is a forum - public or otherwise - viewpoint discrimination is not permitted." 136 Thus, it was unconstitutional for Trump to block users based on viewpoint.

\section{Application of the government speech doctrine}

As noted above, the government is prohibited from engaging in viewpoint discrimination in public fora. One exception to this rule is the government speech doctrine. Under this doctrine, "[t]he Free Speech Clause does not require the government to maintain viewpoint neutrality when its officers and employees speak" about official business. ${ }^{137}$ When the government is the speaker, it may make "content-based choices" to ensure its message is conveyed properly. ${ }^{138}$ This doctrine enables the government to "take legitimate and appropriate steps to ensure that its message is neither garbled nor distorted." 139

The contours of the doctrine can be seen in cases such as Walker v. Texas Division, Sons of Confederate Veterans, Inc. ${ }^{140}$ In Walker, the Supreme Court held that the Texas Department of Motor Vehicles Board could reject a specialty license plate design featuring a Confederate flag.

${ }^{131}$ Lidsky, supra note 120, at 1977.

${ }^{132} \mathrm{Id}$. at 1978.

${ }^{133} I d$. at 1984.

${ }^{134}$ Id. at 1989.

${ }^{135}$ Knight First Amendment Inst. v. Trump, 928 F.3d 226, 237 (2d Cir. 2019) (emphasis added).

${ }^{136} I d$.

${ }^{137}$ Matal v. Tam, 137 S. Ct. 1744, 1757 (2017).

${ }^{138}$ Rosenberger v. Rector and Visitors of Univ. of Virginia, 515 U.S. 819, 833 (1995).

${ }^{139} \mathrm{Id}$. (discussing application of the doctrine in situation where the government uses public funds to promote its message), and citing Rust v. Sullivan, 500 U.S. 173, 194 (1991).

${ }^{140}$ Walker v. Texas Div., Sons of Confederate Veterans, Inc., 135 S. Ct. 2239 (2015). 
Although individuals order and pay extra for specialty license plates, these plates convey government speech. ${ }^{141}$ License plates include messages from and about the states, including pertinent graphics, slogans, and messages. ${ }^{142}$ States are not required to adopt various messages with which they prefer not to identify. The state can "choose how to present itself and its constituency." 143 Texas, which retained authority over the license plate designs, clearly did not intend specialty license plates to serve as any type of public forum. ${ }^{144}$ Thus, it opted not to issue a license plate bearing a Confederate flag because it did not want to be perceived as embracing that message.

The Supreme Court also considered the issue of government speech in Matal v. Tam, which invalidated the disparagement clause of the Lanham Act. ${ }^{145}$ In Matal, a rock singer sought to trademark his group name, "The Slants," which is a derogatory term aimed at the Asian population. ${ }^{146}$ The band members, who are Asian-American, sought to "reclaim" the derogatory term. ${ }^{147}$ The U.S. Patent and Trademark Office (PTO) denied the application because it violated a provision of the Lanham Act that prohibited registering trademarks that "disparage" individuals, beliefs, or institutions. ${ }^{148}$ The PTO unsuccessfully argued that trademarks constitute government speech, and that by issuing a trademark for "The Slants," it would be perceived as the speaker of a derogatory term. ${ }^{149}$ In rejecting the PTO's argument, the Court noted that none of the factors present in Walker inhered in Tam. ${ }^{150}$ A registered trademark is not typically perceived as government messaging, unlike the messages on license plates. The government isn't unwillingly thrust into the role of "speaker" by a trademark.

The government speech doctrine serves two main principles. It protects the government from adopting messages that it does not want to adopt, and it ensures the government's message is insulated from distortion. One measure to achieve the latter goal may ostensibly be curbing criticism that confuses the government's messaging. ${ }^{151}$ But can government officials silence critics on social media to ensure the sanctity of their messaging?

Government speech is notably different from the government use of social media. This difference was articulated by the Fourth Circuit in Davison v. Randall. ${ }^{152}$ When a government official invites discourse and provides a platform for that discourse, there is no danger of garbling or distorting the government's message. First, the constituents' comments are identified by username, and so are clearly not government speech. ${ }^{153}$ And second, the government official invited the discourse and, thus, invited the introduction of nuance and criticism. ${ }^{154}$ The messages put forth by commenters on a public official's social media posts are not attributable to, nor viewed as endorsed by, the public official. Therefore, the government speech doctrine is inapposite here.

${ }^{141}$ Id. at $2246,2248$.

${ }^{142} \mathrm{Id}$. at 2248.

${ }^{143} \mathrm{Id}$.

${ }^{144} I d$. at 2251.

${ }^{145}$ Matal v. Tam, 137 S. Ct. 1744 (2017).

${ }^{146}$ Id. at 1751 .

${ }^{147} \mathrm{Id}$.

${ }^{148} \mathrm{Id}$. at 1753 .

${ }^{149} \mathrm{Id}$. at 1759 .

${ }^{150} \mathrm{Id}$.

151 See Lidsky, supra note 120, at 1992 (stating that when the government shares its views, "it need not include opposing viewpoints").

152 Davison v. Randall, 912 F.3d 666 (4th Cir. 2019).

${ }^{153} I d$. at 686.

${ }^{154} \mathrm{Id}$. 
In considering this issue, the U.S. District Court for the Second Circuit noted that had Trump been engaged in pure government speech, he could have blocked users without running afoul of the First Amendment. ${ }^{155}$ His actions, however, went beyond pure government speech:

It is clear that if President Trump were engaging in government speech when he blocked the Individual Plaintiffs, he would not have been violating the First Amendment. Everyone concedes that the President's initial tweets (meaning those he produces himself) are government speech. But this case does not turn on the President's initial tweets; it turns on his supervision of the interactive features of the Account. ${ }^{156}$

Twitter's interactive features mean that the speech is not solely Trump's government speech; it consists of a myriad of users' "retweets, replies, and likes" that a blocked user cannot access. ${ }^{157}$ The Supreme Court recognized that the government speech doctrine was "susceptible to dangerous misuse." "158 Enabling government officials to bar users from this robust discourse would effectively turn the government speech doctrine into a sword. The government would be encouraged to use the government speech doctrine as a mechanism to "silence or muffle the expression of disfavored viewpoints," realizing the Supreme Court's concerns.

\section{Packingham v. North Carolina (2017)}

In 2017, after having established that social media accounts can function as "metaphysical" public fora, ${ }^{159}$ the Supreme Court turned its attention to speech on social media platforms. Packingham v. North Carolina ${ }^{160}$ is "one of the first" Supreme Court case that analyzes in depth the First Amendment implications of access to social media. ${ }^{161}$

Lester Packingham, a registered sex offender, was arrested for violating a North Carolina law that prohibited sex offenders from accessing commercial social networking sites where children are known to have profiles or webpages. ${ }^{162}$ He argued that the North Carolina statute was unconstitutional, a proposition with which the Supreme Court (9-0) agreed.

The Supreme Court first confirmed that social media is a "metaphysical" public forum, saying, "While in the past there may have been difficulty in identifying the most important places (in a spatial sense) for the exchange of views, today the answer is clear. It is cyberspace - the 'vast democratic forums of the Internet' in general." 163 Because it is a public forum, the government must demonstrate a legitimate basis for banning individuals from social media use. Recognizing the content-neutral nature of the prohibition, the Court applied intermediate scrutiny. It determined

\footnotetext{
${ }^{155}$ Knight First Amendment Inst., 928 F.3d at 239.

${ }^{156} \mathrm{Id}$.

${ }^{157} \mathrm{Id}$.

${ }^{158}$ Matal, 137 S. Ct. at 1758.

159 As Lidsky noted, the lack of physical space "should not preclude a finding of public forum status. Just as the government can rent a building to use as a forum for public debate and discussion, so, too, can it 'rent' a social media page for the promotion of public discussion." Lidsky, supra note 120, at 1996.

${ }^{160}$ Packingham v. North Carolina, 137 S. Ct. 1730 (2017).

${ }^{161}$ According to the Court, "This case is one of the first this Court has taken to address the relationship between the First Amendment and the modern Internet." Id. at 1736.

${ }^{162}$ Id. at 1734. Eight years after Packingham's original conviction for "an offense against a minor," he accessed Facebook and posted a comment (wholly unrelated to his original conviction) about his experience at traffic court. Id. ${ }^{163}$ Id. at 1735.
} 
that the law was unconstitutional because it was not "narrowly tailored to serve a significant government interest."164

The Packingham opinion emphasized equally the right to speak and the right to listen. According to the Court, "A fundamental principle of the First Amendment is that all persons have access to places where they can speak and listen, and then, after reflection, speak and listen once more." 165 The Court was especially troubled by imposing a barrier to access when the internet and social media are involved, stating:

North Carolina with one broad stroke bars access to what for many are the principal sources for knowing current events, checking ads for employment, speaking and listening in the modern public square, and otherwise exploring the vast realms of human thought and knowledge. These websites can provide perhaps the most powerful mechanisms available to a private citizen to make his or her voice heard. ${ }^{166}$

The language in the Court's opinion reflects the rationale in the Court's numerous "right to know" opinions. ${ }^{167}$ The Court concerns itself not just with Packingham's right to convey information, but from his right to receive it on the social media platform.

The opinion also discussed, at length, the democratic promise of social media, a concern central to the right to know cases addressed in this study. ${ }^{168}$ Specifically, the Court recognized the unique potential of the internet for facilitating political participation:

On Facebook, for example, users can debate religion and politics with their friends and neighbors. ... And on Twitter, users can petition their elected representatives and otherwise engage with them in a direct manner. Indeed, Governors in all 50 States and almost every Member of Congress have set up accounts for this purpose. ... In short, social media users employ these websites to engage in a wide array of protected First Amendment activity on topics 'as diverse as human thought.' 169

This language, recognizing the rights of individuals to be fully informed and participate in the democratic process, arguably supports compelled access to government officials' social media accounts. However, this specific issue has not yet been adjudicated by the Supreme Court. In Packingham, the Court even decried the severely limited jurisprudence on First Amendment rights and the internet, particularly social media. ${ }^{170}$ The analogous situations addressed thus far support finding that the Court would view limiting access to these sites as an impermissible restriction on the First Amendment.

\footnotetext{
${ }^{164} \mathrm{Id}$. at 1736 .

165 Id. at 1737 .

${ }^{166} \mathrm{Id}$.

${ }^{167}$ See discussion supra section "The Supreme Court and the right to know," p. 33.

168 See discussion supra section "The right to know furthers the goals of participatory democracy," p. 35.

169 Packingham v. North Carolina, 137 S. Ct. 1730, 1735-1736 (2017) (capitalization in original; internal citations omitted).

${ }^{170}$ The Court recognized that this is one of the first cases involving the First Amendment protection of access to social media. It said, "As a result, the Court must exercise extreme caution before suggesting that the First Amendment provides scant protection for access to vast networks in that medium." Id. at 1736.
} 
The status of public vs. private social media accounts

The parameters of Packingham v. North Carolina guide whether an account qualifies as a public forum. However, while the Packingham majority concluded that social media is a public forum, three justices in concurrence said the majority's position reflected "undisciplined dicta." 171

This question - whether social media accounts are, in fact, public fora - has been taken up in a few cases, and discussed by very few scholars and practitioners. Unsurprisingly, given that this question is relatively novel, the conversation is sparse. There is a general acknowledgement that the public forum analysis should be "functional." 172 Overall, there seems to be a consensus about what factors courts should consider, although there is disagreement regarding whether the factors are determinative or even what result should entail. This section of the study addresses the factors that courts should consider when assessing whether an account is a public forum.

\section{Courts should consider whether the government official's account is 'personal' or 'official'}

By safeguarding Packingham's access to social media, and by extension recognizing the high-value discourse facilitated by preserving social media discourse, the Court broadly proclaimed that social media accounts are public fora. This distinction becomes muddied when considering the fact that the internet, like the physical world, consists of both public and private spaces.

Scholar Rodney Smolla cautioned against reading the language of Packingham too broadly and deeming the internet a "modern digital "public square" without caveat. ${ }^{173}$ Although some spaces are public spaces that naturally warrant robust First Amendment protection, other spaces are private. Smolla suggested that Packingham failed to distinguish between the two spaces and incorrectly determined that social media accounts inherently constitute public fora.

According to Smolla, some spaces on the internet, such as official government websites soliciting constituents' feedback, could be designated public fora. ${ }^{174}$ These spaces are designed specifically to encourage the exchange of information between public officials and constituents. Similarly, an official's social media account on Facebook or Twitter could "very well become designated public for[a] if there are places on the sites for comments posted by citizens." 175

In one of the few Court of Appeals decisions evaluating these issues, Davison v. Randall, the Fourth Circuit resolved the dispute by considering the government official's actions with respect to her social media account. ${ }^{176}$ In that case, Brian Davison brought a 42 U.S.C. $\$ 1983$ claim against Phyllis Randall, the chair of the Loudon County, Virginia, Board of Supervisors. Randall had blocked Davison from her "Chair Phyllis Randall” Facebook page after he criticized

\footnotetext{
${ }^{171} \mathrm{Id}$. at 1738 (Alito, J., concurring).

172 See Lidsky, supra note 120 at 2024 (noting that "[ $\mathrm{t}]$ he public forum inquiry should ... be a functional one based on the way citizens actually use the site."

${ }^{173}$ Rodney A. Smolla, The First Amendment and Public Officials' Social-Media Accounts, 36-SPG DEL. LAW. 22 (Spring 2018).

${ }^{174} I d$. at 23. Most, if not all, scholars would concur with this position. See, e.g., Brian P. Kane, Social Media Is the New Town Square: The Difficulty in Blocking Access to Public Official Accounts, 60-OCT ADVOCATE (Idaho) 31 (October 2017).

175 Smolla, supra note 173, at 23. Smolla also noted that these sites could be "at times classified as organs for the government's own expression, and treated as government speech.”

${ }^{176}$ Davison v. Randall, 912 F.3d 666 (4th Cir 2019).
} 
her official actions regarding the school budget and farm inspections. ${ }^{177}$ The court found that this ban was improper because not only did Randall use the page to communicate with the public, she had designated the page as belonging to a "government official." ${ }^{178}$ Her account became a public forum:

A private citizen could not have created and used the Chair's Facebook Page in such a manner... Put simply, Randall clothed the Chair's Facebook Page in the 'power and prestige of $\mathrm{h}[\mathrm{er}]$ state office,' $\ldots$ and created and administered the page to 'perform actual or apparent dut[ies] of h[er] office.' ${ }^{179}$

The analysis becomes cloudier when considering private social media accounts. The designation that an account is "official" signifies that it, much like a dedicated website, is intended to support the back-and-forth exchange of information between the public official and her constituents. The question becomes whether a public official's private social media account can ever qualify as a public forum.

Smolla suggests the adoption of a "bright-line rule" stating two things. First, governmentheld social media platforms and official accounts could be deemed public fora. ${ }^{180}$ And second, private social media accounts held by public officials cannot, by definition, qualify as public fora. ${ }^{181}$ Public fora are created through specific, intentional governmental action. Private social media accounts, on the other hand, are the property of private social media platforms - not the government. They also reflect the "private choices of political officeholders," and they are governed by different First Amendment principles. ${ }^{182}$

Smolla expressed concern that treating officials' social media accounts as public fora would have deleterious effects. While public fora are neutral by design, officials' private accounts are inherently partisan. Smolla said:

If a public officeholder is forced to treat his or her social-media page as a public forum, the page will lose its character as the officeholder's own unique, individual, candid and authentic expression, and instead become a bowdlerized platform collecting the random messages of any and all, stripped of any distinctive personality or direction. ${ }^{183}$

Smolla's argument is troubling for two reasons.

First, it is unclear how prohibiting government officials from banning constituents would necessarily result in depriving an account of its "distinctive personality or direction." To illustrate, President Trump's Twitter account - which Smolla concedes "may be the single most notorious use of social media by a public officeholder in American society today" 184 - teems with personality. The tenor of Trump's tweets does not appear to be mediated by the composition of his audience. Even though courts have held that his account is a "public forum" and that he must refrain from banning individual access, the fundamental nature of his tweets remains unchanged. Even a cursory glance at President Trump's Twitter account at any time of the day supports this

${ }^{177} I d$. at 675.

${ }^{178} \mathrm{Id}$. at 674 .

${ }^{179} \mathrm{Id}$. at 681 (internal citations omitted).

${ }^{180}$ Smolla, supra note 173 , at 23.

${ }^{181} \mathrm{Id}$.

${ }^{182} \mathrm{Id}$.

${ }^{183} \mathrm{Id}$.

${ }^{184} \mathrm{Id}$ 
claim. He still targeted former Senator John McCain seven months after his passing. ${ }^{185}$ He still attacks the "Radical Left Democrats" and "Fake News Media." 186 And he still suggests that Saturday Night Live is colluding with Democrats to present one-sided coverage of his presidency. ${ }^{187}$ What's perhaps more astonishing is that these three tweets reflect a mere one-hourand-five-minute snapshot of Trump's Twitter account, during which he made numerous other tweets. Smolla's concerns are speculative.

Second, Smolla's asserted concerns are relatively inconsequential when weighed against protecting the constituents' interests in participatory government. He suggests that constituents have "almost infinite channels and platforms" to voice their opinions, but adopting his "bright-line test" would encourage government officials to communicate with constituents via private social media accounts in lieu of government-owned or designated "official" accounts.

Perversely, the more an official seeks to shape the narrative, the more inclined that official would be to use private social media accounts to share critical information. On private platforms, the officials could ban constituents with relative impunity, silencing their contributions to critical political discourse and controlling the story. The result would be severely skewed dialogue and an uninformed populace, the opposite of the "marketplace of ideas" Smolla seeks to perpetuate. Pew Research Internet data even noted a $15 \%$ increase (to $75 \%$ ) in users obtaining their news from Twitter, which may be related to President Trump's use of Twitter to convey information. ${ }^{188}$

Users may have "almost infinite channels and platforms" to air their opinions, as Smolla noted, but this is immaterial. A user who has been blocked by an account on Twitter may have other avenues via which he can receive and comment on the account's tweets, "such as creating new accounts, logging out to view the President's tweets, and using Twitter's search functions to find tweets about the President posted by other users with which they can engage." 189 However, these "workarounds" do not cure the constitutional deficiencies inherent in viewpointdiscrimination-motivated blocking. According to the Supreme Court, "The distinction between laws burdening and laws banning speech is but a matter of degree. The Government's contentbased burdens must satisfy the same rigorous scrutiny as its content-based bans." ${ }^{190}$ Having other avenues to engage in discourse "does not cure that constitutional shortcoming." 191

Impeding users' speech conflicts with the tenets of the First Amendment. As the U.S. Court of Appeals for the Second Circuit noted when it held that the @realDonaldTrump account is a designated public forum, "[T] he best response to disfavored speech on matters of public concern is more speech, not less." 192

\footnotetext{
185 Donald Trump (@realDonaldTrump), TwITTER (Mar. 17, 2019,8:41 a.m.). https://witter.com/realDonaldTrump/status/1107260609974943745 (claiming that John McCain transmitted a dossier to the FBI intending to derail the presidential election). See Michael Tackett, Trump Renews Attacks on John McCain, Months After Senator's Death, N.Y. Times, Mar. 17, 2019,

https://www.nytimes.com/2019/03/17/us/politics/trump-mccain-twitter.html.

186 Donald Trump (@realDonaldTrump), TwITTER (Mar. 17, 2019, 9:18 AM),

https://witter.com/realDonaldTrump/status/1107269978678611969 (capitalization in original) (asserting that the media targeted Judge Jeanine Pirro, which ultimately led to her suspension from Fox News).

${ }^{187}$ Donald Trump (@realDonaldTrump), TwITTER (Mar. 17, 2019,8:13 AM), https://witter.com/realDonaldTrump/status/1107253742271901696.

188 See LoPiano, supra note 15, at 547 (discussing Pew Research data in 2017, and stating that “the President's Twitter account, if not a growing news source itself, may actually be responsible for Twitter's increased audience for news").

${ }^{189}$ Knight First Amendment Inst. v. Trump, 928 F. 3d 226, 238 (2d Cir. 2019).

${ }^{190}$ United States v. Playboy Entm't Grp., Inc., 529 U.S. 803, 812 (2000).

${ }^{191}$ Knight First Amendment Inst., 928 F.3d at 239.

192 Id. at 240.
} 
In its determination, the court noted that while Trump's account was private before he assumed the presidency, and will be private again after leaving the presidency, the pertinent consideration is "what the Account is now." "Trump's account contained numerous indicators that qualify it as a designated public forum:

- Trump uses the account "as a channel for communication and interacting with the public about his administration" 194

- The "public presentation of the Account and the webpage associated with it bear all the trappings of an official, state-run account," including its registration to "Donald J. Trump " $45^{\text {th }}$ President of the United States of America, Washington, D.C." and header photographs depicting engagement in official government business, suggest that this account is intended for government business ${ }^{195}$

- Both the President and administration members have described his account use as "official"196

- The@realDonaldTrump account is “one of the White House's main vehicles for conducting official business"197

- Presidential tweets are presumably official records, according to the National Archives and the Presidential Records Act of 1978. ${ }^{198}$

As noted by the court, the @realDonaldTrump account "was intentionally opened for public discussion" and used "as an official vehicle for governance," and "its interactive features [were] accessible to the public without limitation." 199 Therefore, it is a public forum.

\section{Courts should analyze the content posted by the account}

Individual access to public officials' social media accounts arguably turns on the purpose of their use. Some scholars suggest that, in line with Packingham, social media is a public forum. Government officials' social media accounts should be deemed public fora when they are used to convey government information to - and receive it from - constituents. Others suggest that this position is unsound because it relies too heavily on Packingham's dicta.

Brian Kane, the Deputy Attorney General for the State of Idaho, suggested that an account's public forum status should turn on the extent to which it facilitates the exchange of information between public officials and constituents. ${ }^{200}$ Thus, President Trump's private @ realDonaldTrump Twitter account is a designated public forum because he uses this account to engage in dialogue about important government information with his constituents. An individual blocked from accessing that social media account would be able to bring a 42 U.S.C. $§ 1983$

\footnotetext{
193 Id. at 6.

194 Id. at 7.

${ }^{195} \mathrm{Id}$. at $7,17$.

${ }^{196} \mathrm{Id}$.

197 Id. at 8 .

198 Id. at 9.

199 Id. at 23.

${ }^{200}$ Kane, supra note 174, at 32 (noting that an account that "both distributes information to constituents and receives information from constituents" would likely be deemed a public forum). Kane proposed six factors to consider here, including the reason for the account's creation, the owner's identity, whether public resources are used to maintain the account, the purpose of the account, whether the account is "swathed in the trappings of office," and what content is posted. $I d$.
} 
claim. ${ }^{201}$ The aggrieved individual would be required to demonstrate that the ban (1) was imposed under "color of law," and (2) deprived the constituent of his constitutional rights. ${ }^{202}$ If the individual can make this showing, then the ban would be held unconstitutional.

Rodney Smolla, on the other hand, disputes the propriety of analyzing public officials' purpose in this way. He asserts that this is "not a sound way to frame or analyze the issue." 203 According to Smolla, "The question of whether an official is acting under 'color of law' or engaged in 'state action' should not be conflated with the separate First Amendment question of how and when a public forum comes into existence." 204

The few courts analyzing this question have repudiated Smolla's position. In Davison v. Randall, the Fourth Circuit evaluated a 42 U.S.C. $\$ 1983$ claim brought by a constituent who was banned by an elected public official, Phyllis Randall, from her "Chair Phyllis Randall" Facebook page. ${ }^{205}$ The court reviewed de novo the question of whether Randall used her page in such a way that it became a public forum. ${ }^{206}$ This determination hinged on Randall's activities with respect to the Facebook page. The court said that in creating and administering the Facebook account, and banning a constituent, Randall acted under color of state law. ${ }^{207}$

Randall used her page as a "tool of governance," not only by designating the page as belonging to a "government official," 208 but sharing information with the public, and inviting constituent feedback. ${ }^{209}$ These latter two concerns, specifically the encouragement of public comment, were deemed determinative. ${ }^{210}$ The court also explicitly rejected Randall's argument that Facebook is private and thus cannot be a public forum. ${ }^{211}$ The court raised several examples in which forum analysis had previously extended to private property that was designated for public use or which was controlled by the government. ${ }^{212}$

The Davison opinion recognizes that a government official cannot disavow the official capacity of her actions by conveying information via a private social media account. The opinion also refuses to enable government officials to use these accounts to obfuscate criticism of their official actions.

A similar rationale was employed by the U.S. Court of Appeals for the Second Circuit in determining that @realDonaldTrump is a designated public forum. ${ }^{213}$ The court considered the numerous capacities in which the account was used to convey information and solicit feedback about various government policies. ${ }^{214}$ Trump himself stipulated that he used the account...

\footnotetext{
${ }^{201} I d$.

${ }^{202} \mathrm{Id}$.

${ }^{203}$ Smolla, supra note 173 , at 24.

${ }^{204} \mathrm{Id}$.

${ }^{205}$ Davison v. Randall, 912 F.3d 666 (4th Cir. 2019) Although the court ultimately discussed Packingham, it correctly noted that no courts had previously considered the specific issue of whether a governmental social media page constituted a public forum. $I d$. at 682 .

${ }^{206} \mathrm{Id}$. at 681 .

${ }^{207} \mathrm{Id}$. at $680-81$.

208 See discussion supra section 'Courts should consider whether the government official's account is 'personal' or 'official,"” p. 51. (addressing the impact of Randall designating this account as an "official" account).

${ }^{209}$ Davison, 912 F.3d at 674.

${ }^{210} \mathrm{Id}$.

${ }^{211} I d$. at $682-83$.

${ }^{212} \mathrm{Id}$. at 683.

${ }^{213}$ Knight First Amendment Inst., 928 F.3d at 238.

${ }^{214} I d$. at 231-32.
} 
... [T]o announce, describe and defend his policies; to promote his Administration's legislative agenda; to announce official decisions; to engage with foreign political leaders; to publicize state visits; [and] to challenge media organizations whose coverage of his Administration he believes to be unfair. ${ }^{215}$

The court considered the various official activities Trump used the account to communicate about, including: nominating Christopher Wray as FBI director, announcing the administration's ban on transgender individuals serving in the military, announcing that he fired Chief of Staff Reince Preibus and replaced him with General John Kelly, and updating the public on his discussions with South Korean President Moon Jae-in about North Korea's nuclear capabilities. ${ }^{216}$ These uses of the account - "as an important tool of governance and executive outreach" ${ }^{217}$ - militates against treating it as a private account.

Furthermore, the account also invites users to "Follow for the latest from @POTUS @ realDonaldTrump and his Administration." ${ }^{218}$ By its nature, "public interaction [is] a prominent feature of the account." 219

It should be noted that the court explained that, ordinarily, there may be a fact-specific inquiry when the ways a public official actually uses his account diverge from the ways he characterizes the account. ${ }^{220}$ These issues were not present in Trump's case. However, the court suggested that such a determination would depend on the following factors: how the official describes and uses the account; to whom the features of the account are made available; and how others, including government officials and agencies, regard and treat the account. ${ }^{221}$

The general trend suggests that public officials' social media accounts are public fora. By extension, government officials, therefore, cannot engage in viewpoint discrimination to ban or block users. However, the case law and jurisprudence regarding this specific question are sparse. The concerns of scholars such as Rodney Smolla may persuade a court to carve out and define "private" social media spaces based on the characteristics of social media use. Furthermore, the assertion that private social media accounts are not government property, but the property of private social media platforms, should be given special consideration.

\section{Conclusion}

The Supreme Court has established that the Constitution includes a penumbral "right to know," which recognizes an individual's interest in securing information about government operations. The relevant case law centered around two themes. The first theme is access to publicly available information. The Court protects an individual's right to access this information, especially where access furthers the goals of a participatory democracy. The Court also has stated that absent a compelling reason, the government is prohibited from contracting available information or propounding any undue burden in obtaining that information. The second theme is

\footnotetext{
${ }^{215} I d$. at 231.

${ }^{216} \mathrm{Id}$.

${ }^{217} I d$. at 236 .

${ }^{218} I d$. at 235 .

${ }^{219} \mathrm{Id}$. at 236 .

${ }^{220} \mathrm{Id}$.

${ }^{221} \mathrm{Id}$.
} 
access to compelled information. The Court has typically declined to force the government to reveal information that is not already known to the public.

Various mechanisms have been put in place to protect and further the right of individuals to access publicly available information. The most obvious of these is the statutory protections afforded by FOIA. Although FOIA includes many important protections for safeguarding access, it comes with some problems that render it ineffective in safeguarding an individual's right of access here. First, statutes involving access yield inconsistent results, especially in the face of government inertia. And second, the statutes' reach is limited, leaving individuals unable to use the statutory mechanisms to secure certain important documents.

This background information raises the question of how courts would evaluate the public's right to access the social media accounts of public officials, particularly their private social media accounts. To address this question, the study first discussed forum analysis, determining that certain of the officials' social media accounts would likely be deemed a metaphysical public forum. This determination would limit public officials' ability to curb speech on their accounts.

The study next turned to, and rejected, the government speech doctrine as applied to social media accounts. The doctrine enables government officials to silence certain discourse if it would impede or distort the government speaker's messaging. Had it applied, it could empower officials to silence speech on their social media accounts. However, the rationale behind the government speech doctrine simply does not extend to public officials' social media accounts.

Then, the study considered the most directly relevant Supreme Court case, Packingham v. North Carolina, which established the principle that social media accounts are public fora. ${ }^{222}$ The Court's position was clear; however, there are reasonable arguments for determining that Packingham's reading may be overbroad. Instead, social media consists of various private and public spaces. Public officials' social media accounts may fall in one or the other of these categories, depending on context. It also considered Knight First Amendment Institute at Columbia University v. Trump, ${ }^{223}$ a U.S. Court of Appeals for the Second Circuit decision that determined that Trump's@realDonaldTrump account, though technically "private," functioned as a public forum; thus, Trump cannot engage in viewpoint discrimination to ban users from interacting with the account. ${ }^{224}$

And finally, the study addressed the account characteristics a court may consider when determining whether individuals can claim a right to access a public official's social media account. The court may consider whether the account is designated as "official" or "private." The former accounts are more likely to be deemed public because their designation suggests that the information includes official government business intended for the public to view and respond to. Scholars differ, however, regarding whether individuals can assert a legitimate right to access the private social media accounts of public officials. On one hand, the "private" designation suggests that the account is not intended for public consumption. This, plus the fact that the accounts are owned by private companies, not the government, weighs against access. On the other hand, the "private" designation shouldn't be used to shield accounts from the public eye, especially if critical government business is being conducted through the private account. This indicates that the court should consider the content posted to the social media account. If the account is used to share

\footnotetext{
222137 S. Ct. 1730 (2017).

223928 F.3d 226 (2d Cir. 2019).

${ }^{224} I d$. at 234.
} 
important government information, and solicit feedback from constituents, then there would be a strong argument for access.

More robust protections for access must be secured. The Packingham court did much of the heavy lifting when it comes to paving the way for individual access to public officials' social media accounts. And certainly, the (few) courts that have considered access to these social media accounts have held in line with Packingham, supporting broad access. But even with Packingham's broad, protective language, there is still room to suggest that public officials are empowered to wield excessive control on social media accounts designated as "private." This result would be a perverse misreading of the law, creating a technicality that furthered the goals of disinformation, misinformation, and censorship. Thus, there should be clear guidelines regarding when social media accounts are public fora. These guidelines would instruct courts not only to consider the account designation, but to engage in a substantive analysis of the nature of the account. If a "private" account is being used to engage in back-and-forth discourse with constituents about official government matters, then it would almost certainly be a public forum, designation notwithstanding.

These rules would ensure two things. It would help protect an individual's right to access important government information and further the principles of participatory democracy. And it and it would help ensure that "private" social media spaces are actually private and not being used to conduct government business outside the public's eye. 